\title{
Dexamethasone Treatment after the First Week of Life for Bronchopulmonary Dysplasia in Preterm Infants: A Systematic Review
}

\author{
Lex W. Doyle ${ }^{a}$ Richard A. Ehrenkranz ${ }^{b}$ Henry L. Hallidayc \\ a Departments of Obstetrics and Gynaecology, and Paediatrics, University of Melbourne, The Royal Women's \\ Hospital, and Murdoch Children's Research Institute, Melbourne, Vic., Australia; ${ }^{b}$ Department of Pediatrics, \\ Yale University School of Medicine, New Haven, Conn., USA; 'Department of Child Health, Queen's University \\ Belfast and Perinatal Medicine, Royal Jubilee Maternity Service, Belfast, UK
}

\section{Key Words}

Dexamethasone $\cdot$ Bronchopulmonary dysplasia $\cdot$ BPD,

preterm infants $\cdot$ Mortality rate $\cdot$ Cerebral palsy

\begin{abstract}
Background: Dexamethasone has powerful anti-inflammatory effects and has been used to treat established bronchopulmonary dysplasia (BPD), but it is uncertain whether the benefits outweigh the risks of treatment. Objectives: To determine the effect of late ( $>7$ days) postnatal dexamethasone treatment compared with control (placebo or nothing) to prevent or treat BPD in the preterm infant. Methods: Randomised controlled trials (RCTs) of late postnatal dexamethasone therapy to treat or prevent BPD were sought using methods of the Cochrane Collaboration. Data regarding clinical outcomes including mortality, BPD, death or BPD, complications during the primary hospitalisation, and long-term outcome were abstracted and analysed using RevMan 5. Results: 19 RCTs enrolling 1,345 participants were eligible for this review. Late dexamethasone treatment reduced neonatal mortality, but not later mortality. Benefits of late dexamethasone included reductions in failure to extubate, BPD and the combined outcome of death or BPD. There were clear short-term complications, including hyperglycaemia and hypertension, but not intestinal perforation. Trends of
\end{abstract}

an increase in cerebral palsy or abnormal neurological examination were partly offset by a trend in the opposite direction in death before late follow-up. Conclusions: The benefits of late dexamethasone may not outweigh actual or potential adverse effects. Given the evidence of both benefits and harms of treatment, and the limitations of the evidence at present, it appears prudent to reserve the use of late dexamethasone to infants who cannot be weaned from mechanical ventilation, and to minimise the dose and duration of any course of treatment.

Copyright $\odot 2010$ S. Karger AG, Basel

\section{Background}

Bronchopulmonary dysplasia (BPD) is a major problem for newborn babies in neonatal intensive care units, and is associated with both a higher death rate and worse long-term outcomes in survivors [1]. Persistent inflammation of the lungs is a major contributor to BPD, and hence corticosteroids, because of their strong anti-inflammatory effects, appeal as a drug to either prevent or

Supported in part by Project Grant No. 108700 from the National Health and Medical Research Council, Australia.

\section{KARGER}

Fax +41613061234 E-Mail karger@karger.ch www.karger.com

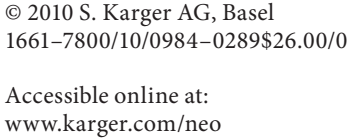

Prof. L.W. Doyle

Department of Obstetrics and Gynaecology, The Royal Women's Hospital

20 Flemington Rd, Parkville, Vic. 3052 (Australia)

Tel. +61 38345 3716, Fax +61 383453702

E-Maillwd@unimelb.edu.au 
treat BPD, particularly in babies who cannot be weaned from assisted ventilation. Postnatal corticosteroids have some acute effects on lung function in infants with established BPD, especially those who are ventilator-dependent $[2,3]$. However, there is concern that the benefits of corticosteroids might not outweigh the adverse effects [4], and animal studies have also raised concerns about adverse effects of corticosteroids $[5,6]$.

Of the corticosteroids available, dexamethasone is the one that has been most extensively evaluated in clinical trials. Broadly speaking, investigators have aimed either to prevent BPD by starting treatment during the first week of life, or they have treated evolving or established BPD, with treatment started after the first week of life. The risks of dexamethasone started in the first week of life outweigh the benefits, as reviewed elsewhere $[7,8]$. The aim of this study was to review systematically the data from randomised controlled trials (RCTs) in newborn infants where dexamethasone was compared with placebo, to establish the balance between risks and benefits of such treatment in newborn infants in the prevention or treatment of BPD when treatment was started after the first 7 days of age. This report is a synthesis of the more clinically important outcomes, all of which are detailed in the recently updated Cochrane Review [9].

\section{Methods}

Data were sought on all RCTs of postnatal dexamethasone treatment started after the first week of life for preterm infants with or developing BPD defined as oxygen dependence and/or ventilator dependence, with or without radiographic changes of BPD, that reported clinically important outcomes. The intervention compared dexamethasone, either orally or parenterally, with either placebo or nothing. The outcomes included mortality, BPD defined usually as needing oxygen at either at 28 days or 36 weeks, death or BPD, late rescue with corticosteroids, survivors discharged home on oxygen, failure to extubate, complications during the primary hospitalisation (including infection, hyperglycaemia, glycosuria, hypertension, hypertrophic cardiomyopathy, necrotising enterocolitis (NEC), gastrointestinal (GI) bleeding, GI perforation, and severe retinopathy of prematurity (ROP), and long-term outcomes (including blindness, deafness, cerebral palsy and major neurosensory disability).

RCTs of postnatal corticosteroid therapy were sought from the Cochrane Controlled Trials Register, MEDLINE, hand-searching paediatric and perinatal journals, examining previous review articles and information received from practising neonatologists. MEDLINE was searched from 1966 through March 2009 using the terms adrenal cortex hormones or dexamethasone or steroids or corticosteroids and limits RCTs, human, all infant: birth -23 months. Meta-analysis of data from the included trials was per- formed using RevMan 5. For some statistically and clinically significant outcomes the number needed to treat for additional beneficial (NNTB) or harmful (NNTH) outcomes and 95\% confidence intervals (CIs) were calculated from the typical relative risks according to methods of the Cochrane Handbook for Systematic Reviews of Interventions [10], assuming the control group event rate as the baseline rate. Significant heterogeneity was present if the $\mathrm{I}^{2}$ statistic was $>50 \%$, suggesting caution when interpreting the results of meta-analysis.

\section{Results}

Nineteen RCTs qualified for inclusion in this review $[3,11-28]$. These trials enrolled preterm infants who were oxygen- and/or ventilator-dependent beyond 7 days of age. All trials used dexamethasone; there were no trials of other corticosteroids. The starting dose of dexamethasone was typically as high as $0.5-1.0 \mathrm{mg} / \mathrm{kg} / \mathrm{day}$, with the duration of therapy varying between 3 days and up to 6 weeks. Details of the subjects included in the studies and the dexamethasone regimens are listed in table 1.

Details of individual trial methods are listed in table 2. All were randomised trials, but the method of random allocation was not always described. Treatment allocation was mostly concealed from the study investigators. Blinding of intervention from the investigators was by use of placebos in most studies, and blinding of outcome measures and complete reporting of in-hospital outcomes for infants randomised applied to most studies. Not all trials had follow-up components; those that did had reasonable to excellent ( $>90 \%)$ follow-up rates. However, ages of assessment were often only into early childhood and not to school-age in the majority of studies reporting outcomes after discharge home.

\section{Results of Meta-Analysis}

The results of the meta-analysis of these 19 studies of late dexamethasone treatment, including the NNTB and NNTH where results were statistically significant, are shown in table 3 and figures 1 and 2.

Mortality and Acute Lung Morbidity. Late steroid treatment was associated with reduced mortality at 28 days, but had no significant effect on mortality at the latest reported age (table 3). BPD was significantly decreased at both 28 days of postnatal age and at 36 weeks of PMA. The combined outcome of mortality or BPD was decreased at both 28 days' postnatal age and 36 weeks' PMA. In addition to these major benefits, dexamethasone had other respiratory advantages - it reduced the need for late corticosteroids, the need for 
Table 1. Types of subjects and dexamethasone regimens

\begin{tabular}{|c|c|c|c|c|}
\hline $\begin{array}{l}\text { First author, year } \\
\text { [reference] }\end{array}$ & Subjects & Dexamethasone regimen & $\begin{array}{l}\text { Total dose } \\
\mathrm{mg} / \mathrm{kg}\end{array}$ & $\begin{array}{l}\text { Duration } \\
\text { days }\end{array}$ \\
\hline $\begin{array}{l}\text { Avery } \\
1985[11]\end{array}$ & $\begin{array}{l}\mathrm{n}=16 ; \mathrm{BW}<1,500 \mathrm{~g} \text {; inability to be weaned from } \\
\text { the ventilator after } 2 \text { weeks and radiological } \\
\text { evidence of stage II or III Northway BPD [33] }\end{array}$ & $\begin{array}{l}0.5 \mathrm{mg} / \mathrm{kg} / \text { day for } 3 \text { days; } 0.3 \mathrm{mg} / \mathrm{kg} / \text { day for } 3 \text { days; } \\
\text { then decreased by } 10 \% \text { every } 3 \text { days until } 0.1 \mathrm{mg} / \mathrm{kg} / \text { day; } \\
0.1 \mathrm{mg} / \mathrm{kg} / \text { day alternate days for } 1 \text { week }\end{array}$ & 8.0 & 42 \\
\hline $\begin{array}{l}\text { Ariagno } \\
1987[12]\end{array}$ & $\begin{array}{l}\mathrm{n}=34 ; \mathrm{BW}<1,501 \mathrm{~g} ; 3 \text { weeks of age; } \\
\text { ventilator-dependent }\end{array}$ & $\begin{array}{l}\text { (a) } 1.0 \mathrm{mg} / \mathrm{kg} / \text { day for } 4 \text { days; } 0.5 \mathrm{mg} / \mathrm{kg} / \text { day for } 6 \text { days } \\
\text { (b) } 1.0 \mathrm{mg} / \mathrm{kg} / \text { day for } 4 \text { days; } 0.5 \mathrm{mg} / \mathrm{kg} / \text { day for } 4 \text { days }\end{array}$ & $\begin{array}{l}7.0 \\
5.0\end{array}$ & $\begin{array}{r}10 \\
7\end{array}$ \\
\hline $\begin{array}{l}\text { Cummings } \\
1989[13]\end{array}$ & $\begin{array}{l}\mathrm{n}=36 ; \mathrm{BW}<1,251 \mathrm{~g} ; \mathrm{GA}<31 \text { weeks; } \\
\text { oxygen-dependent }(>29 \%) ; \text { mechanical ventilation } \\
\text { (rate }>14 \text { per min); no weaning during the previous } \\
72 \mathrm{~h} ; 2 \text { weeks of age }\end{array}$ & $\begin{array}{l}\text { (a) } 0.5 \mathrm{mg} / \mathrm{kg} / \text { day for } 3 \text { days; } 0.3 \mathrm{mg} / \mathrm{kg} / \text { day for } 3 \text { days; } \\
\text { then decreased by } 10 \% \text { every } 3 \text { days until } 0.1 \mathrm{mg} / \mathrm{kg} / \mathrm{day} \text {; } \\
0.1 \mathrm{mg} / \mathrm{kg} / \text { day alternate days for } 1 \text { week } \\
\text { (b) } 0.5 \mathrm{mg} / \mathrm{kg} / \text { day for } 3 \text { days; reduced by } 50 \% \text { every } \\
3 \text { days until } 0.06 \mathrm{mg} / \mathrm{kg} \text { on days } 10,11 \text { and } 12 ; 0.06 \mathrm{mg} / \\
\mathrm{kg} / \text { day on alternate days for } 1 \text { week }\end{array}$ & 2.98 & 42 \\
\hline $\begin{array}{l}\text { Noble-Jamieson } \\
1989[14]\end{array}$ & $\mathrm{n}=18 ;>4$ weeks; $>30 \%$ oxygen & $\begin{array}{l}0.5 \mathrm{mg} / \mathrm{kg} \text { for } 7 \text { days } 0.25 \mathrm{mg} / \mathrm{kg} \text { for } 7 \text { days; } 0.1 \mathrm{mg} / \mathrm{kg} \\
\text { for } 7 \text { days }\end{array}$ & 5.95 & 21 \\
\hline $\begin{array}{l}\text { Harkavy } \\
1989[15]\end{array}$ & $\mathrm{n}=21$ ventilator-dependent; 30 days of age & $0.5 \mathrm{mg} / \mathrm{kg} /$ day for minimum of 14 days & $\begin{array}{l}7 \\
\text { minimum }\end{array}$ & $\begin{array}{l}14 \text { mini- } \\
\text { mum }\end{array}$ \\
\hline $\begin{array}{l}\text { Kazzi } \\
1990[16]\end{array}$ & $\begin{array}{l}\mathrm{n}=23 ;<1,500 \mathrm{~g} \mathrm{BW} ; \mathrm{BPD} \text { on } \mathrm{X} \text {-ray; } 3-4 \text { weeks of } \\
\text { age; ventilator-dependent; }>34 \% \text { oxygen; rate }>14 \\
\text { breaths/min; inspiratory pressure }>17 \mathrm{~cm} \mathrm{H}_{2} \mathrm{O} ; \text { no } \\
\text { weaning } 5 \text { days }\end{array}$ & $\begin{array}{l}0.50 \mathrm{mg} / \mathrm{kg} / \text { day for } 3 \text { days; } 0.40 \mathrm{mg} / \mathrm{kg} / \text { day for } 2 \text { days; } \\
0.25 \mathrm{mg} / \mathrm{kg} / \text { day for } 2 \text { days; then hydrocortisone } 8 \mathrm{mg} / \\
\mathrm{kg} / \text { day for } 2 \text { days; } 4 \mathrm{mg} / \mathrm{kg} / \text { day for } 2 \text { days; } 2 \mathrm{mg} / \mathrm{kg} / \text { day } \\
\text { for } 2 \text { days; } 1 \mathrm{mg} / \mathrm{kg} / \text { day for } 2 \text { days; } 0.5 \mathrm{mg} / \mathrm{kg} / \text { day for } \\
2 \text { days }\end{array}$ & $\begin{array}{l}2.8 ; \\
31 \mathrm{mg} \mathrm{HC}\end{array}$ & 17 \\
\hline $\begin{array}{l}\text { Collaborative } \\
\text { Dexamethasone } \\
\text { Trial Group } \\
1991[3]\end{array}$ & $\begin{array}{l}n=287 \text { infants oxygen-dependent; static or } \\
\text { deteriorating over the preceding week; from around } \\
3 \text { weeks of age. Not all mechanically ventilated }\end{array}$ & $\begin{array}{l}0.6 \mathrm{mg} / \mathrm{kg} / \text { day for } 1 \text { week. Option of a second tapering } \\
9 \text {-day course; } 0.6,0.4 \text {, and } 0.2 \mathrm{mg} / \mathrm{kg} / \text { day for } 3 \text { days each }\end{array}$ & $\begin{array}{l}3.5 \\
\text { minimum }\end{array}$ & $\begin{array}{l}7 \text { mini- } \\
\text { mum }\end{array}$ \\
\hline $\begin{array}{l}\text { Ohlsson } \\
1992[17]\end{array}$ & $\begin{array}{l}\mathrm{n}=25 ;<1,501 \mathrm{~g} \mathrm{BW} ; 21-35 \text { days of age; } \mathrm{X} \text {-ray of } \\
\mathrm{BPD} ;>29 \% \text { oxygen; ventilator-dependent }\end{array}$ & $\begin{array}{l}1 \mathrm{mg} / \mathrm{kg} \text { for } 3 \text { days; } 0.5 \mathrm{mg} / \mathrm{kg} / \text { days for } 3 \text { days; } 0.25 \mathrm{mg} / \\
\mathrm{kg} / \text { day for } 3 \text { days; } 0.125 \mathrm{mg} / \mathrm{kg} / \text { daily for } 3 \text { days }\end{array}$ & 5.62 & 12 \\
\hline $\begin{array}{l}\text { Kari } \\
1993[18]\end{array}$ & $\begin{array}{l}\mathrm{n}=41 ;<1,501 \mathrm{~g} \mathrm{BW} ;>23 \text { weeks' GA; } \\
\text { ventilator-dependent; } 10 \text { days of age }\end{array}$ & $0.5 \mathrm{mg} / \mathrm{kg} /$ day for 7 days & 3.5 & 7 \\
\hline $\begin{array}{l}\text { Brozanski } \\
1995[19]\end{array}$ & $\mathrm{n}=78 ; \mathrm{BW}<1,501 \mathrm{~g} ; 7$ days of age & $\begin{array}{l}0.5 \mathrm{mg} / \mathrm{kg} / \text { day } 12 \text { hourly for } 3 \text { days at } 10 \text {-day intervals } \\
\text { until no longer required supplemental oxygen or } \\
\text { assisted ventilation, or reached } 36 \text { weeks' PMA }\end{array}$ & $\begin{array}{l}1.5 \\
\text { minimum }\end{array}$ & $\begin{array}{l}3 \text { mini- } \\
\text { mum }\end{array}$ \\
\hline $\begin{array}{l}\text { Durand } \\
1995[20]\end{array}$ & $\begin{array}{l}\mathrm{n}=43 ; 600-1,500 \mathrm{~g} \text { BW; } 24-32 \text { weeks' GA; } \\
\text { ventilator-dependent at } 14 \text { days; not weaning }\end{array}$ & $\begin{array}{l}0.5 \mathrm{mg} / \mathrm{kg} / \text { day } 3 \text { days; } 0.25 \mathrm{mg} / \mathrm{kg} / \text { day } 3 \text { days; } 0.1 \mathrm{mg} / \\
\mathrm{kg} / \text { day } 1 \text { day }\end{array}$ & 2.35 & 7 \\
\hline $\begin{array}{l}\text { Kovacs } \\
1998[21]\end{array}$ & $\begin{array}{l}\mathrm{n}=60 ;<1,501 \mathrm{~g} \mathrm{BW} ;<30 \text { weeks } \mathrm{GA} ; \\
\text { ventilator-dependent; } 7 \text { days }\end{array}$ & $\begin{array}{l}0.5 \mathrm{mg} / \mathrm{kg} / \text { day for } 3 \text { days; budesonide } 500 \mu \mathrm{g} / \text { day for } 18 \\
\text { days }\end{array}$ & 1.5 & 3 \\
\hline $\begin{array}{l}\text { Papile } \\
1998[22]\end{array}$ & $\begin{array}{l}\mathrm{n}=371 ;<1,501 \mathrm{~g} \text { BW; ventilator-dependent; } \\
\text { respiratory index }>2.4 ; 14 \text { days of age }\end{array}$ & $\begin{array}{l}0.5 \mathrm{mg} / \mathrm{kg} / \mathrm{day} \text { for } 5 \text { days; then } 0.3 \mathrm{mg} / \mathrm{kg} / \text { day for } 3 \text { days, } \\
\text { then } 0.14 \mathrm{mg} / \mathrm{kg} / \text { day for } 3 \text { days, then } 0.06 \mathrm{mg} / \mathrm{kg} / \text { day for } \\
3 \text { days }\end{array}$ & 4 & 14 \\
\hline $\begin{array}{l}\text { Romagnoli } \\
1998[23]\end{array}$ & $\begin{array}{l}\mathrm{n}=30 ; 10 \text { days of age; ventilator-dependent; }>90 \% \\
\text { chance of BPD }\end{array}$ & $\begin{array}{l}0.5 \mathrm{mg} / \mathrm{kg} / \mathrm{day} \text { for } 6 \text { days; } 0.25 \mathrm{mg} / \mathrm{kg} / \text { day for } 6 \text { days; } \\
0.125 \mathrm{mg} / \mathrm{kg} / \text { day for } 3 \text { days }\end{array}$ & 4.87 & 15 \\
\hline Vincer 1998 [24] & $\mathrm{n}=20$; ventilator-dependent; 30 days of age & $0.5 \mathrm{mg} / \mathrm{kg} /$ day for 3 days; $0.3 \mathrm{mg} / \mathrm{kg} /$ day for 3 days & 2.4 & 6 \\
\hline $\begin{array}{l}\text { Kothadia } \\
1999[25]\end{array}$ & $\begin{array}{l}\mathrm{n}=118 ;<1,501 \mathrm{~g} \mathrm{BW} ; 15-25 \text { days of age; } \\
\text { ventilator-dependent }\end{array}$ & $\begin{array}{l}0.5 \mathrm{mg} / \mathrm{kg} / \text { day for } 3 \text { days; } 0.3 \mathrm{mg} / \mathrm{kg} / \text { day for } 3 \text { days; then } \\
\text { decreased by } 10 \% \text { every } 3 \text { days until } 0.1 \mathrm{mg} / \mathrm{kg} / \text { day; } 0.1 \\
\mathrm{mg} / \mathrm{kg} / \text { day alternate days for } 1 \text { week }\end{array}$ & 8.0 & 42 \\
\hline $\begin{array}{l}\text { Walther } \\
2003[26]\end{array}$ & $\begin{array}{l}24-32 \text { weeks } \mathrm{GA} ;>599 \mathrm{~g} \text { BW; ventilator-dependent; } \\
>29 \% \text { oxygen; } 7-14 \text { days of age }\end{array}$ & $\begin{array}{l}0.2 \mathrm{mg} / \mathrm{kg} / \text { day for } 4 \text { days; } 0.15 \mathrm{mg} / \mathrm{kg} / \text { day for } 4 \text { days; } \\
0.1 \mathrm{mg} / \mathrm{kg} / \text { day for } 4 \text { days, and } 0.05 \mathrm{mg} / \mathrm{kg} / \text { day for } 2 \text { days }\end{array}$ & 1.9 & 14 \\
\hline $\begin{array}{l}\text { Vento } \\
2004[27]\end{array}$ & $\begin{array}{l}\mathrm{n}=20 ;<1,251 \mathrm{~g} \mathrm{BW} ;<33 \text { weeks } \mathrm{GA} ; \\
\text { ventilator-dependent; } 10 \text { days }\end{array}$ & $\begin{array}{l}0.5 \mathrm{mg} / \mathrm{kg} / \mathrm{day} \text { for } 3 \text { days, } 0.25 \mathrm{mg} / \mathrm{kg} / \text { day for } 3 \text { days and } \\
0.125 \mathrm{mg} / \mathrm{kg} / \text { day for } 1 \text { day }\end{array}$ & 2.35 & 7 \\
\hline $\begin{array}{l}\text { Doyle } \\
2006[28]\end{array}$ & $\begin{array}{l}\mathrm{n}=70 ; \mathrm{BW}<1,000 \mathrm{~g} \text { or } \mathrm{GA}<28 \text { weeks; } \geq 7 \text { days of } \\
\text { age; ventilator-dependent }\end{array}$ & $\begin{array}{l}0.15 \mathrm{mg} / \mathrm{kg} / \text { day for } 3 \text { days; } 0.10 \mathrm{mg} / \mathrm{kg} / \text { day for } 3 \text { days; } \\
0.05 \mathrm{mg} / \mathrm{kg} / \text { day for } 2 \text { days; } 0.02 \mathrm{mg} / \mathrm{kg} / \text { day for } 2 \text { days }\end{array}$ & 0.89 & 10 \\
\hline
\end{tabular}


Table 2. Assessment of bias in reported studies

\begin{tabular}{|c|c|c|c|c|c|c|c|}
\hline $\begin{array}{l}\text { First author, year } \\
\text { [reference] }\end{array}$ & $\begin{array}{l}\text { Adequate } \\
\text { method for } \\
\text { randomisation }\end{array}$ & $\begin{array}{l}\text { Blinding of } \\
\text { randomisation }\end{array}$ & $\begin{array}{l}\text { Blinding of } \\
\text { intervention }\end{array}$ & $\begin{array}{l}\text { Complete FU } \\
\text { reporting }\end{array}$ & $\begin{array}{l}\text { Blinding of } \\
\text { outcome } \\
\text { assessment }\end{array}$ & $\begin{array}{l}\text { Age } \\
\text { latest FU }\end{array}$ & $\begin{array}{l}\text { FU rate } \\
\%\end{array}$ \\
\hline Avery, 1985 [11] & yes & yes & unsure & yes & uncertain & NA & NA \\
\hline Ariagno, 1987 [12] & yes & yes & yes & yes & yes & 36 months & 96 \\
\hline Cummings, $1989[13,34]$ & yes & yes & yes & yes & yes & $\begin{array}{l}\text { (a) } 15 \text { months } \\
\text { (b) } 4 \text { years } \\
\text { (c) } 15 \text { years }\end{array}$ & $\begin{array}{l}\text { (a) } 100 \\
\text { (b) } 100 \\
\text { (c) } 100\end{array}$ \\
\hline Noble-Jamieson, 1989 [14] & unclear & unclear & yes & yes & yes & NA & NA \\
\hline Harkavy, 1989 [15] & yes & yes & yes & yes & $21 / 22$ & $6-24$ months & 32 \\
\hline Kazzi, 1990 [16] & yes & yes & yes & yes & yes & NA & NA \\
\hline CDTG, $1991[3,35-37]$ & yes & yes & yes & yes & yes & $\begin{array}{l}\text { (a) } 3 \text { years } \\
\text { (b) } 13-17 \text { years }\end{array}$ & $\begin{array}{l}\text { (a) } 94 \\
\text { (b) } 77\end{array}$ \\
\hline Ohlsson, 1992 [17] & yes & yes & yes & yes & attempted & 18 months & 96 \\
\hline Kari, $1993[18,38]$ & unclear & yes & yes & yes & yes & $2-9$ years & 80 \\
\hline Brozanski, $1995[19,39]$ & yes & yes & yes & no $(78 / 88)$ & yes & 12 months & 68 \\
\hline Durand, 1995 [20] & yes & yes & yes & yes & $43 / 44$ & NA & NA \\
\hline Kovacs, 1998 [21] & yes & yes & yes & yes & yes & up to 90 months & 70 \\
\hline Papile, 1998 [22] & yes & yes & yes & yes & yes & NA & NA \\
\hline Romagnoli, $1998[23,40]$ & yes & yes & no & yes & unclear & $36-42$ months & 100 \\
\hline Vincer, 1998 [24] & unclear & unclear & unclear & yes & yes & 24 months & 100 \\
\hline Kothadia, $1999[25,41,42]$ & unclear & unclear & yes & yes & yes & $\begin{array}{l}\text { (a) } 12 \text { months } \\
\text { (b) } 4-11 \text { years }\end{array}$ & $\begin{array}{l}\text { (a) } 98 \\
\text { (b) } 88\end{array}$ \\
\hline Walther, 2003 [26] & yes & yes & yes & yes & yes & NA & NA \\
\hline Vento, 2004 [27] & unclear & unclear & no & yes & unclear & NA & NA \\
\hline Doyle, $2006[28,43]$ & yes & yes & yes & yes & yes & 2 years & 98 \\
\hline
\end{tabular}

NA $=$ Not applicable.

${ }^{\text {a }}$ For outcomes during primary hospitalisation.

home oxygen, and the rate of failure to extubate by 7 days.

Complications during the Primary Hospitalisation. Dexamethasone after the first week of life was associated with many short-term complications, such as higher rates of hyperglycaemia and glycosuria, high blood pressure, severe ROP, and hypertrophic cardiomyopathy. There were no significant increases in rates of infection, or in GI problems, such as NEC, GI bleeding or GI perforation.

Follow-Up Data. The increase in ROP did not translate into a significant increase in blindness. There were no significant differences in the rates of deafness, cerebral palsy at the latest reported age, or the combined rate of either death or cerebral palsy at the latest reported age. Major neurosensory disability was not significantly increased, but the number of studies where this outcome could be determined $(n=7)$ was smaller than the number of studies reporting cerebral palsy outcomes $(n=12)$. The combined rate of either death or major neurosensory disability was not significantly affected. There was an in- creased rate of abnormal neurological examination overall, but there were only four studies reporting this outcome, and the clinical importance of this finding is unclear in the absence of important increases in either cerebral palsy or major neurosensory disability.

Pooled rates of selected outcomes for both treated and control groups, and the relative risks and 95\% CIs for benefit are shown in figure 1 and for harm are shown in figure 2.

\section{Discussion}

In this systematic review, infants who were mostly ventilator-dependent after the first week of life were transiently improved by a course of dexamethasone initiated after the first 7 days of life. Dexamethasone facilitated extubation from the ventilator and reduced the rate of BPD, the need for a later course of corticosteroids and the need for home oxygen therapy. Survival to 28 days was 
Table 3. Meta-analysis of selected outcomes, and NNTB or NNTH where differences were statistically significant

\begin{tabular}{|c|c|c|c|c|c|}
\hline Outcome & Studies & Infants & $\begin{array}{l}\text { Typical relative risk } \\
(95 \% \mathrm{CI})\end{array}$ & $\mathrm{p}$ value & $\begin{array}{l}\text { NNTB or NNTH } \\
(95 \% \text { CI })\end{array}$ \\
\hline \multicolumn{6}{|l|}{ Mortality and acute lung morbidity } \\
\hline Mortality at 28 days & 8 & 656 & $0.49(0.28-0.85)$ & 0.01 & $19(14-63)$ \\
\hline Mortality at latest reported age & 16 & 936 & $0.87(0.67-1.13)$ & 0.29 & \\
\hline BPD at 28 days & 6 & 623 & $0.87(0.81-0.94)^{\mathrm{a}}$ & $<0.001$ & $9(6-20)$ \\
\hline Death or BPD at 28 days & 5 & 563 & $0.84(0.78-0.89)$ & $<0.001$ & $7(5-10)$ \\
\hline BPD at 36 weeks & 8 & 471 & $0.72(0.61-0.85)^{\mathrm{a}}$ & $<0.001$ & $6(4-11)$ \\
\hline Death or BPD at 36 weeks & 8 & 471 & $0.72(0.63-0.82)^{\mathrm{a}}$ & $<0.001$ & $5(4-8)$ \\
\hline Failure to extubate by 7 days & 10 & 497 & $0.64(0.56-0.74)$ & $<0.001$ & $4(3-5)$ \\
\hline Late rescue with corticosteroids & 12 & 1,032 & $0.46(0.36-0.58)$ & $<0.001$ & $6(5-8)$ \\
\hline Discharge home on oxygen & 7 & 611 & $0.71(0.54-0.94)$ & 0.02 & $13(8-62)$ \\
\hline \multicolumn{6}{|l|}{ Other early complications } \\
\hline Infection & 14 & 1,225 & $1.17(0.98-1.39)$ & 0.08 & \\
\hline Hyperglycaemia & 14 & 1,192 & $1.52(1.25-1.84)$ & $<0.001$ & $10(7-21)$ \\
\hline Glycosuria & 2 & 48 & $8.03(2.43,26.52)$ & $<0.001$ & $2(1-9)$ \\
\hline Hypertension & 12 & 1,096 & $2.66(1.58-4.49)$ & $<0.001$ & $21(10-59)$ \\
\hline Hypertrophic cardiomyopathy & 4 & 238 & $2.76(1.33-5.74)^{\mathrm{a}}$ & 0.006 & $9(4-45)$ \\
\hline NEC & 8 & 952 & $0.98(0.56-1.73)$ & 0.95 & \\
\hline Intestinal perforation & 2 & 95 & $0.36(0.02-8.05)$ & 0.52 & \\
\hline Gastrointestinal bleeding & 7 & 992 & $1.38(0.99-1.93)$ & 0.06 & \\
\hline Severe ROP & 12 & 558 & $1.38(1.07-1.79)$ & 0.01 & $12(6-60)$ \\
\hline \multicolumn{6}{|l|}{ Long-term follow-up } \\
\hline Blindness & 9 & 621 & $0.81(0.32-2.04)$ & 0.66 & \\
\hline Deafness & 6 & 458 & $0.56(0.22-1.44)$ & 0.23 & \\
\hline Abnormal neurological exam & 4 & 200 & $1.81(1.05-3.11)$ & 0.03 & $8(3-122)$ \\
\hline Cerebral palsy at latest age assessed & 12 & 756 & $1.22(0.84-1.77)$ & 0.30 & \\
\hline Death or cerebral palsy & 12 & 756 & $0.98(0.80-1.21)$ & 0.87 & \\
\hline Major neurosensory disability & 7 & 612 & $1.19(0.86-1.66)$ & 0.30 & \\
\hline Death or major neurosensory disability & 7 & 612 & $1.07(0.88-1.30)$ & 0.51 & \\
\hline
\end{tabular}

Typical relative risks and $95 \% \mathrm{CIs}<1$ indicate a significant benefit from treatment with dexamethasone and those $>1$ indicate harm. a Significant heterogeneity $\left(\mathrm{I}^{2}>50 \%\right)$.

improved, but whether this was maintained overall is unclear, partly because of the high rate of open-label use of corticosteroids in most studies, and because the results of Papile et al. [22] could not be used for survival outcomes beyond 28 days because of treatment of the majority of the delayed group with dexamethasone after that time. However, there were significant short-term side effects of dexamethasone, including hyperglycaemia, glycosuria, hypertension and cardiomyopathy, and some evidence of longer-term side effects, including severe ROP and abnormal neurological examination. The methodological quality of the studies determining the long-term outcome was limited in some cases; surviving children were assessed predominantly before school age, and no study was sufficiently powered to detect important adverse long-term neurosensory outcomes. Given the evidence of both benefits and harms of treatment, and the limitations of the evidence at present, it appears prudent to reserve the use of late corticosteroids to infants who cannot be weaned from mechanical ventilation after the first week of life and who are at high risk of BPD [29], and to minimise the dose and duration of any course of treatment.

A subgroup analysis limited to those studies where there was no open-label corticosteroid treatment was considered, but where it was possible to determine if open-label corticosteroids were allowed, they were prescribed in most trials. Open-label corticosteroids make it harder to determine the true effects of dexamethasone alone. There were too few studies with too few subjects where it is known for certain that open-label corticoste- 


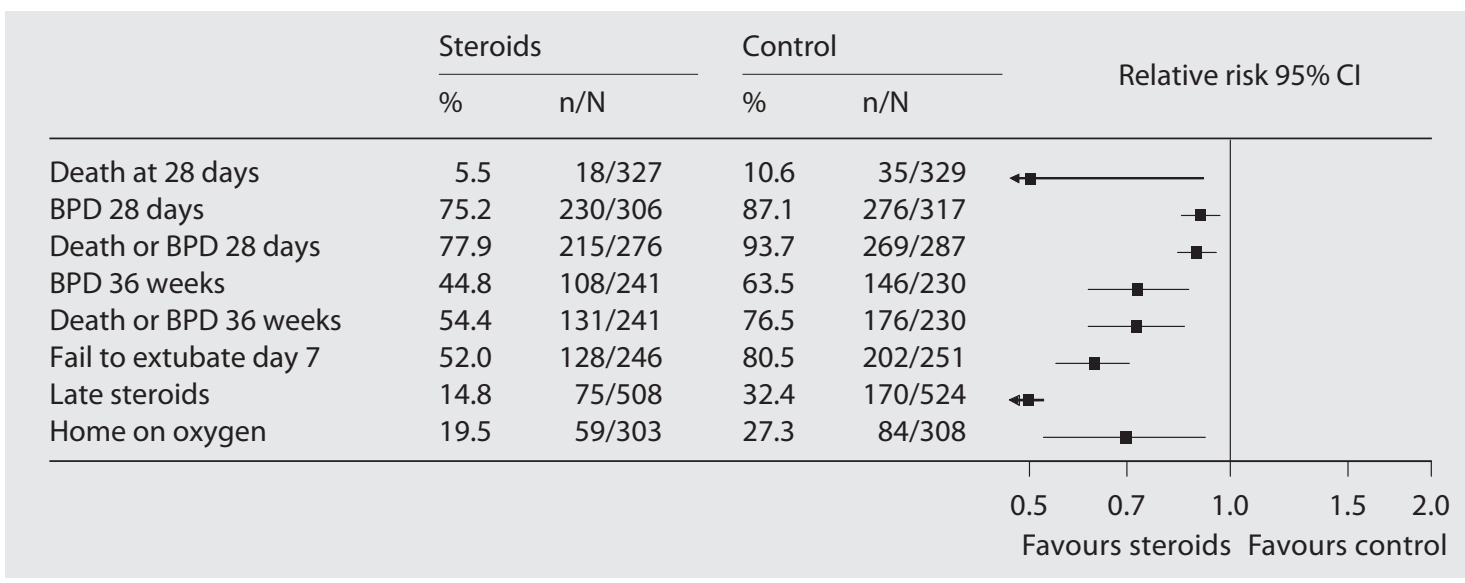

Fig. 1. Forest plot of typical relative risks for favourable outcomes from late dexamethasone.

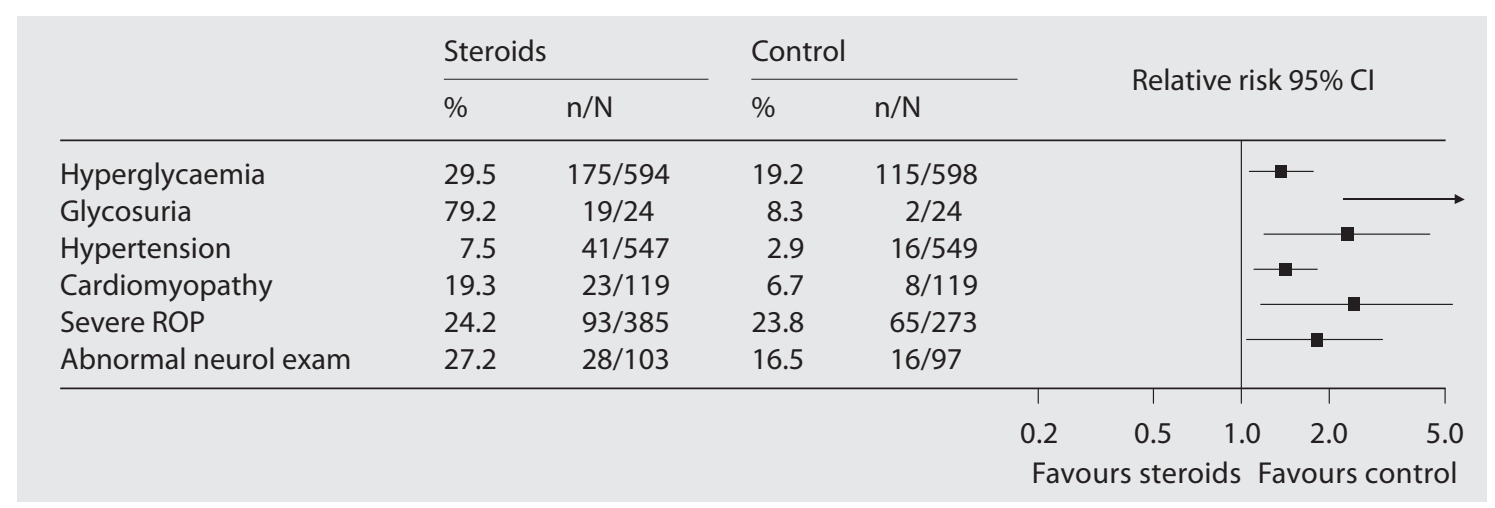

Fig. 2. Forest plot of typical relative risks for adverse outcomes from late dexamethasone.

roids were not prescribed to justify such a subgroup analysis.

More studies are needed to examine the lowest safe dose and type of corticosteroid. Hydrocortisone, and other corticosteroids such as betamethasone or methylprednisolone, should be compared with lower doses of dexamethasone in ventilator-dependent infants. Thus far, hydrocortisone is the only other systemic corticosteroid to be evaluated in RCTs; it has only been started in the first week of life in relatively low doses, where it has few effects, as reviewed elsewhere [7, 30]. Long-term follow-up studies on all children who have been enrolled in randomised trials of dexamethasone are required. These studies need to examine both major and more subtle (e.g. cognitive and behavioural) adverse neurological outcomes, in addition to long-term visual function. Any new studies should be designed to assess the overall risks and benefits of corticosteroids and be sufficiently powered to detect important adverse long-term neurosensory sequelae.

In this review, data on long-term neurosensory followup were available from 12 studies comprising 800 infants randomised, but these were of varying methodological quality. The significant increase in abnormal neurological examination in those randomised is of potential concern; however, this is tempered by the findings that cerebral palsy and major neurosensory disability, both overall and in survivors, were not significantly increased, and the abnormal neurological examination findings were reported in only 4 of the 11 follow-up studies and in only 200 subjects randomised. It should be noted, however, that some studies reporting cerebral palsy as an outcome 
did so early in childhood; before 5 years of age the diagnosis of cerebral palsy is not certain in all cases [31]. Moreover, no study was designed primarily to test the effect of postnatal corticosteroids on adverse long-term neurosensory outcome, except for the DART study [28], which had to cease recruitment with $<10 \%$ of the projected sample size recruited, and all were underpowered to detect clinically important differences in long-term neurosensory outcome. Clearly more information on long-term outcome of infants is needed.

Clinicians must weigh the benefits of acute improvement in respiratory function and increased chances of extubation (with a possible improved survival) against the potential detrimental effects, both metabolic and neurological. Dexamethasone may be a harmful drug to the immature brain and consideration must be given to limiting its use to situations where it is essential to achieve weaning from the ventilator. Lower doses and shorter courses should be considered for these infants; the DART study [28], with a total dose of only $0.89 \mathrm{mg} / \mathrm{kg}$ over 10 days, was able to demonstrate acute benefits of extubation and reduced respiratory support. There are limited data on the effects of inhaled corticosteroids in infants with $\mathrm{BPD}$, but this potentially useful intervention should have fewer systemic side effects and warrants further study [32]. Further studies of low-dose systemic corticosteroids initiated beyond the first week of life in infants at high risk of developing BPD are also warranted.

\section{References}

1 Ehrenkranz RA, Walsh MC, Vohr BR, Jobe AH, Wright LL, Fanaroff AA, Wrage LA, Poole K: Validation of the National Institutes of Health consensus definition of bronchopulmonary dysplasia. Pediatrics 2005;116: 1353-1360.

$\checkmark 2$ Mammel MC, Green TP, Johnson DE, Thompson TR: Controlled trial of dexamethasone therapy in infants with bronchopulmonary dysplasia. Lancet 1983;1:13561358.

-3 Collaborative Dexamethasone Trial Group: Dexamethasone therapy in neonatal chronic lung disease: an international placebo-controlled trial. Pediatrics 1991;88:421-427.

4 American Academy of Pediatrics, Committee on Fetus and Newborn, and Canadian Paediatric Society, Fetus and Newborn Committee: Postnatal corticosteroids to treat or prevent chronic lung disease in preterm infants. Pediatrics 2002;109:330-338.

-5 Taeusch HW Jr: Glucocorticoid prophylaxis for respiratory distress syndrome: a review of potential toxicity. J Pediatr 1975;87:617-623.

66 Weichsel ME Jr: The therapeutic use of glucocorticoid hormones in the perinatal period: potential neurological hazards. Ann Neurol 1977;2:364-366.

7 Halliday HL, Ehrenkranz RA, Doyle LW: Early ( $<8$ days) postnatal corticosteroids for preventing chronic lung disease in preterm infants. Cochrane Database Syst Rev 2009:CD001146.

$\checkmark 8$ Doyle LW, Ehrenkranz RA, Halliday HL: Dexamethasone treatment in the first week of life for preventing bronchopulmonary dysplasia in preterm infants: a systematic review. Neonatology 2010;98:217-224.
9 Halliday HL, Ehrenkranz RA, Doyle LW: Late ( $>7$ days) postnatal corticosteroids for chronic lung disease in preterm infants. Cochrane Database Syst Rev 2009:CD001145.

10 Higgins JPT, Green S: Cochrane Handbook for Systematic Reviews of Interventions Version 5.0.0 (updated February 2008). Higgins JPT, Green S (eds): The Cochrane Collaboration, 2008. Available from www.cochranehandbook.org.

-11 Avery GB, Fletcher AB, Kaplan M, Brudno DS: Controlled trial of dexamethasone in respirator-dependent infants with bronchopulmonary dysplasia. Pediatrics 1985;75: 106-111.

12 Ariagno RL, Sweeney TJ, Baldwin RB, Inguillo D, Martin D: Dexamethasone effects on lung function and risks in 3-week-old ventilatory-dependent preterm infants. Am Rev Respir Dis 1987;135:A125.

13 Cummings JJ, D’Eugenio DB, Gross SJ: A controlled trial of dexamethasone in preterm infants at high risk for bronchopulmonary dysplasia. N Engl J Med 1989;320:15051510.

$>14$ Noble-Jamieson CM, Regev R, Silverman M: Dexamethasone in neonatal chronic lung disease: pulmonary effects and intracranial complications. Eur J Pediatr 1989;148:365367.

15 Harkavy KL, Scanlon JW, Chowdhry PK, Grylack LJ: Dexamethasone therapy for chronic lung disease in ventilator- and oxygen-dependent infants: a controlled trial. J Pediatr 1989;115:979-983.

16 Kazzi NJ, Brans YW, Poland RL: Dexamethasone effects on the hospital course of infants with bronchopulmonary dysplasia who are dependent on artificial ventilation. Pediatrics 1990;86:722-727.
$>17$ Ohlsson A, Calvert SA, Hosking M, Shennan AT: Randomized controlled trial of dexamethasone treatment in very-low-birthweight infants with ventilator-dependent chronic lung disease. Acta Paediatr 1992;81: 751-756.

18 Kari MA, Heinonen K, Ikonen RS, Koivisto M, Raivio KO: Dexamethasone treatment in preterm infants at risk for bronchopulmonary dysplasia. Arch Dis Child 1993;68:566569.

19 Brozanski BS, Jones JG, Gilmour CH, Balsan MJ, Vazquez RL, Israel BA, Newman B, Mimouni FB, Guthrie RD: Effect of pulse dexamethasone therapy on the incidence and severity of chronic lung disease in the very low birth weight infant. J Pediatr 1995;126:769776.

20 Durand M, Sardesai S, McEvoy C: Effects of early dexamethasone therapy on pulmonary mechanics and chronic lung disease in very low birth weight infants: a randomized, controlled trial. Pediatrics 1995;95:584-590.

21 Kovacs L, Davis GM, Faucher D, Papageorgiou A: Efficacy of sequential early systemic and inhaled corticosteroid therapy in the prevention of chronic lung disease of prematurity. Acta Paediatr 1998;87:792-798

22 Papile LA, Tyson JE, Stoll BJ, Wright LL, Donovan EF, Bauer CR, Krause-Steinrauf H, Verter J, Korones SB, Lemons JA, Fanaroff AA, Stevenson DK: A multicenter trial of two dexamethasone regimens in ventilator-dependent premature infants. N Engl J Med 1998;338:1112-1118.

$>23$ Romagnoli C, Zecca E, Vento G, Maggio L, Papacci P, Tortorolo G: Effect on growth of two different dexamethasone courses for preterm infants at risk of chronic lung disease. A randomized trial. Pharmacology 1999;59:266-274. 
-24 Vincer M, Allen AC: Double-blind randomized controlled trial of 6-day pulse of dexamethasone for very low birth weight infants $(<1,500 \mathrm{~g})$ who are ventilator-dependent at 4 weeks of age (sic). Pediatr Res 1998;43:201A.

25 Kothadia JM, O'Shea TM, Roberts D, Auringer ST, Weaver RG 3rd, Dillard RG: Randomized placebo-controlled trial of a 42-day tapering course of dexamethasone to reduce the duration of ventilator dependency in very low birth weight infants. Pediatrics 1999;104:22-27.

26 Walther FJ, Findlay RD, Durand M: Adrenal suppression and extubation rate after moderately early low-dose dexamethasone therapy in very preterm infants. Early Hum Dev 2003;74:37-45.

-27 Vento G, Matassa PG, Zecca E, Tortorolo L, Martelli M, De Carolis MP, Maggio L, Zini G, D’Onofrio G, Valentini S, Romagnoli C: Effect of dexamethasone on tracheobronchial aspirate fluid cytology and pulmonary mechanics in preterm infants. Pharmacology 2004;71:113-119.

-28 Doyle LW, Davis PG, Morley CJ, McPhee A, Carlin JB: Low-dose dexamethasone facilitates extubation among chronically ventilator-dependent infants: a multicenter, international, randomized, controlled trial. Pediatrics 2006;117:75-83.

$\checkmark 29$ Doyle LW, Halliday HL, Ehrenkranz RA, Davis PG, Sinclair JC: Impact of postnatal systemic corticosteroids on mortality and cerebral palsy in preterm infants: effect modification by risk for chronic lung disease. Pediatrics 2005;115:655-661.
30 Doyle LW, Ehrenkranz RA, Halliday HL: Postnatal hydrocortisone for preventing or treating bronchopulmonary dysplasia in preterm infants: a systematic review. Neonatology 2010;98:111-117.

31 Stanley FJ: Using cerebral palsy data in the evaluation of neonatal intensive care: a warning. Dev Med Child Neurol 1982;24 93-94.

32 Bassler D, Halliday HL, Plavka R, Hallman M, Shinwell ES, Jarreau PH, Carnielli V, van den Anker J, Schwab M, Poets CF: The Neonatal European Study of Inhaled Steroids (NEUROSIS): An EU-funded international randomised controlled trial in preterm infants. Neonatology 2009;97:52-55.

33 Northway WH Jr, Rosan RC, Porter DY: Pulmonary disease following respirator therapy of hyaline-membrane disease. Bronchopulmonary dysplasia. N Engl J Med 1967;276: 357-368.

34 Gross SJ, Anbar RD, Mettelman BB: Followup at 15 years of preterm infants from a controlled trial of moderately early dexamethasone for the prevention of chronic lung disease. Pediatrics 2005;115:681-687.

35 Jones R, Wincott E, Elbourne D, Grant A: Controlled trial of dexamethasone in neonatal chronic lung disease: a 3-year follow-up. Pediatrics 1995;96:897-906.

36 Jones RA: Randomized, controlled trial of dexamethasone in neonatal chronic lung disease: 13- to 17-year follow-up study. II. Respiratory status, growth, and blood pressure. Pediatrics 2005;116:379-384.

37 Jones RA: Randomized, controlled trial of dexamethasone in neonatal chronic lung disease: 13- to 17-year follow-up study. I Neurologic, psychological, and educational outcomes. Pediatrics 2005;116:370-378.
38 Mieskonen S, Eronen M, Malmberg LP, Turpeinen M, Kari MA, Hallman M: Controlled trial of dexamethasone in neonatal chronic lung disease: an 8-year follow-up of cardiopulmonary function and growth. Acta Paediatr 2003;92:896-904.

39 Hofkosh D, Brozanski BS, Edwards MD, Williams LA, Jones JG, Cheng KP: One year outcome of infants treated with pulse dexamethasone for prevention of BPD. Pediatr Res 1995;37:259A.

40 Romagnoli C, Zecca E, Luciano R, Torrioli G, Tortorolo G: A three-year follow-up of preterm infants after moderately early treatment with dexamethasone. Arch Dis Child Fetal Neonatal Ed 2002;87:F55-F58.

41 O'Shea TM, Kothadia JM, Klinepeter KL, Goldstein DJ, Jackson BG, Weaver RG 3rd, Dillard RG: Randomized placebo-controlled trial of a 42-day tapering course of dexamethasone to reduce the duration of ventilator dependency in very low birth weight infants: outcome of study participants at 1-year adjusted age. Pediatrics 1999;104:15-21.

42 O’Shea TM, Washburn LK, Nixon PA, Goldstein DJ: Follow-up of a randomized, placebo-controlled trial of dexamethasone to decrease the duration of ventilator dependency in very low birth weight infants: neurodevelopmental outcomes at 4 to 11 years of age. Pediatrics 2007;120:594-602.

43 Doyle LW, Davis PG, Morley CJ, McPhee A, Carlin JB: Outcome at 2 years of age of infants from the DART study: a multicenter, international, randomized, controlled trial of low-dose dexamethasone. Pediatrics 2007; 119:716-721 